tym miejscom. Może dzięki książkom artystycznym będziemy doświadczać ich w nowy sposób?
DOI: http://dx.doi.org/10.12775/SE.2020.00023 Akademia Sztuk Pięknych im. Eugeniusza Gepperta we Wrocławiu, kontakt:m.wosik@asp.wroc.pl,

ORCID ID: 0000-0003-2321-6026

Sztuka Edycji 1/2020 ISSN 2084-7963 (print) ISSN 2391-7903 (online) s. $269-271$

${ }^{2}$ A. Carson, If Not, Winter: Fragments of Sappho, London 2002.

${ }^{3}$ A. Juchnowicz, Let's call it Lace Stitch, „Artist's Book Yearbook 2020/21” 2019, s. 25

${ }^{4}$ A. MacLennan, Konteksty, http://www.contexts.com.pl/pl/artysci/alastair-maclennan-11 (dostęp: 3.11.2019).

EE. Čiricaite, In the Space of Time, „Artist's Book Yearbook 2018/19” 2017, http://www. bookarts.uwe.ac.uk/artists-book-yearbook/ (dostęp: 3.11.2019).

${ }^{6}$ Lamiel, https://www.lamiel-art.fr/ (dostęp: 3.11.2019).

7 J. Irving, Aleja tajemnic, tłum. M. Moltzan-Małkowska, Warszawa 2016.

\section{Magdalena Wosik}

\section{BOOKmacherzy... ...czyli pokażcie, co macie w szufladach}

\author{
Cykl prezentacji studenckich \\ książek i ilustracji 2016-2020
}

W 2016 roku jako kierownikowi Katedry Projektowania Graficznego ${ }^{1}$ udało mi się zmobilizować moich kolegów i moje koleżanki do współpracy przy inicjatywie, której pomysł dojrzewał we mnie już od dawna. Przystąpiliśmy do organizowania monumentalnej prezentacji dorobku Katedry w dziedzinie tworzenia ilustracji i książki. Ze względu na profil wystawy to pracownicy i studenci związani z dwiema Pracowniami - Książki i Ilustracji - stali się głównymi jej organizatorami. W naturalny sposób kuratorami zostali niżej podpisana Magdalena Wosik, Joanna Skrzypiec-Żuchowska i Karolina M. Wiśniewska, prowadzące Pracownię Książki, oraz Tomasz Broda odpowiedzialny za Pracownię Ilustracji.

Warto wspomnieć o jeszcze jednym impulsie, który mobilizował nas do działania. Były to procesy zachodzące 
wewnątrz Katedry Projektowania Graficznego, przede wszystkim zmiana jej struktury. Chodziło nam o zdecydowane zaznaczenie - także w nazewnictwie - profilu każdej z sześciu pracowni dyplomujących, do tej pory nazywanych tak samo: Pracowniami Projektowania Graficznego. Wcześniej rozróżniane głównie przez nazwiska prowadzących, od teraz w nazwach miały anonsować swój profil. Właśnie wtedy Pracownia Książki i Pracownia Ilustracji zaczęły funkcjonować tak jak pozostałe pracownie przemianowane zgodnie z profilem artystycznej działalności swoich prowadzących. Wcześniej książki powstawały niemal w każdej z pracowni, teraz miało się to zmienić. Nadszedł czas, by zebrać nasz dotychczasowy dorobek o wspólnym mianowniku „książka”.

Zebrać i pokazać, krzycząc bardzo głośno: zobaczcie, jakie piękne rzeczy robimy! Opowiedzieliśmy o idei wystawy Rektorowi Akademii i to on umożliwił nam postawienie naprawdę ogromnego wykrzyknika. Profesor Piotr Kielan zaprosił nas do Narodowego Forum Muzyki ${ }^{2}$. Ta przestrzeń onieśmielała, ale była wyzwaniem i szansą na skomponowanie czegoś niezwykłego.

Muszę zaznaczyć, że praca nad tym, by wystawa doszła do skutku, to efekt kolektywnej katedralnej współpracy. Jednym z pierwszych działań na rzecz ekspozycji angażujących większość z nas było zebranie obiektów, a także uzupełnienie dokumentacji fotograficznej, co okazało się ogromnym wyzwaniem. Wiele zdjęć $\mathrm{z}$ archiwum nie spełniało naszych oczekiwań. Trudno było wykorzystać je do stworzenia spójnej prezentacji i w związku z tym czekało nas sporo pracy. Szczęśliwie, mieliśmy wsparcie Jerzego Buławy z katedralnego Laboratorium Wzorca Odbitki Poligraficznej. Mogliśmy we własnym zakresie wykonać dokumentację, wykorzystać ją do zaprojektowania plansz, a te następnie wydrukować.

Głównym założeniem wystawy było pokazanie ciekawych realizacji studenckich ze wszystkich pracowni Katedry. Następnym - zaangażowanie studentów do wykonania oprawy graficznej. Chodziło nam o to, by młodzi twórcy od początku chcieli się identyfikować z tym wydarzeniem. W Pracowni Książki i Pracowni Ilustracji w ramach zadania semestralnego przeprowadziliśmy konkurs na jego identyfikację wizualną. Autorem wybranego znaku i projektu plakatu okazał się Paweł Kaczmarczyk, dzisiaj już absolwent Akademii. Cały czas intensywnie zastanawialiśmy się nad tytułem. Ostatecznie wybraliśmy hasło zaproponowane przez naszego kolegę, Tomasza Brodę: „BOOKmacherzy”. To my! Wszyscy uczestnicy wystawy mogli - i mam nadzieję chcieli - utożsamiać się z tym tytułem. Istotny jest jego charakterystyczny zapis, ponieważ widząc hasło, łatwiej odczytujemy ukrytą w nim zabawę i niejednoznaczność. Ale tytuł działa intrygująco także wtedy, gdy go tylko wypowiadamy czy słyszymy - hasło jest zwięzłe, zaskakujące i zmusza do szukania kontekstu.

Jednocześnie trwały prace nad układem prezentacji i jej zawartością. Wystawa składała się z kilku części - została zaprojektowana do konkretnej przestrzeni na czwartym poziomie Narodowego Forum Muzyki we Wrocławiu. Towarzyszyło nam pytanie, jak rozwiązać paradoks - kameralny w odbiorze przedmiot trzeba bowiem zaprezentować w monumentalnych wnętrzach. Zagraliśmy kontrastami. Obok książek wykorzystaliśmy bardzo powiększone, wydrukowane na wielkich formatach plansze, odnoszące się do fotografii obiektów i reprodukcji ilustracji, które na ścianach tworzyły kolorowe płaszczyzny.

Postanowiliśmy umownie podzielić ekspozycję w rozległej, ale niejednorodnej przestrzeni. Na poszczególnych ścianach pokazaliśmy plansze z realizacjami w różnych stylistykach. Powstała część bardziej klasyczna, ale i komiksowa. „Na wystawie spotkają się projekty bezkompromisowych komiksiarzy, grubą krechą kreślących okrutne niekiedy portrety naszej rzeczywistości z przepięknymi, lirycznymi ilustracjami zarówno do literackiej klasyki, jak i do autorskich tekstów. Jan Brzechwa idzie tu pod rękę z Witoldem Gombrowiczem, Andrzej Waligórski z Jane Austen. Znajdziemy tu podwórkowe historie ze świdnickiego blokowiska, lokalne opowieści z podczęstochowskiego Poraja i przaśny słownik polsko-rosyjski dla miłośników mocnych wrażeń. A dla miłośników subtelności - oniryczna baśń prosto z kanadyjskiego lasu”3. Tak - bez koloryzowania - anonsowaliśmy BOOKmacherów, zapraszając do odwiedzenia wystawy.

Zaplanowaliśmy kilka niespodzianek dla widzów. Pojawił się prawdziwy słup ogłoszeniowy do ekspozycji graficznych anonsów matrymonialnych. Ich autorka - Beata Filipowicz w 2017 roku obroniła oparty na nich dyplom ${ }^{4}$. Jedną ze ścian wypełniło trzysta sześćdziesiąt pięć kartek z książeczki w formie kalendarza-zdzieraka, czyli 365 dni z życia myszy Weroniki Leciak, także pracy dyplomowej obronionej w 2017 roku. Dopełnieniem całości była prezentacja na planszach i w gablocie opraw introligatorskich, wykonanych przez studentów podczas warsztatów artystycznego oprawiania książki, przeprowadzonych rok wcześniej przez Katię Zubakhinę.

Jako organizatorom zależało nam na tym, żeby ekspozycja była przyjazna dla odbiorcy, aby pojawiło się na niej jak najwięcej obiektów przeznaczonych do bezpośredniego kontaktu - wzięcia do rąk i obejrzenia. W ten sposób można było zaprezentować jedynie książki wydane w większych nakładach. Studenckie projekty w formie makiet, ze względu 
na ich unikatowy charakter, zostały umieszczone w gablotach. Przede wszystkim z tego właśnie powodu zapadła decyzja o rozszerzeniu ekspozycji o dzieła pedagogów.

Wydane drukiem książki powieszone na linkach zajęly całą ścianę. Były to głównie realizacje pracowników Katedry, ale udało się też dołączyć do ekspozycji kilka prac studenckich - cezurą było to, aby w przypadku tych obiektów powstały one w momencie, gdy ich autorzy mieli jeszcze status studenta. To oczywiście bardzo ograniczyło liczbę tych pozycji, ale stały się one niewątpliwie atrakcją tej części wystawy. Pokazaliśmy książkę z ilustracjami Diany Karpowicz Lukrecja (do tekstu Przemysława Wechterowicza, wyd. Ezop Agencja Edytorska), Skaczacy Myszka z ilustracjami Julity Nowosad (tekst Briana Pattena, wyd. Biuro Literackie) oraz autorską Kawalerkę Weroniki Przybylskiej (wyd. Dwie Siostry; Laureatka nagrody głównej jury w międzynarodowym konkursie na projekt ilustrowanej książki dla dzieci JASNOWIDZE $2014)^{5}$.

Wystawie towarzyszyło - z założenia ulotne - wydawnictwo w formie zestawu pocztówek z ilustracjami. Minikatalog został zamknięty w tekturowym pudełku i zaklejony banderolą - naklejką z logotypem „BOOKmacherów”. Wydawnictwo także powstało niemal bezkosztowo, siłami Katedry.

Opisana przeze mnie odsłona wystawy pokazana na przełomie 2016 i 2017 roku $^{6}$ w Narodowym Forum Muzyki była dotychczas wystawą najobszerniejszą. Już w czasie jej trwania dostaliśmy zaproszenie do pokazania ekspozycji w Galerii Casa Matei, gdzie BOOKmacherzy zagościli w marcu 2017 roku, z zaprzyjaźnionego z wrocławską Akademią Uniwersytetu Artystycznego w Kluż-Napoka ${ }^{7}$ w Rumunii.

Odsłonę pierwszą BOOKmacherów zauważył i także zaprosił do współpracy ówczesny dyrektor Wrocławskiego Domu Literatury - pan dr Jan Choroszy. Dzięki temu pod koniec 2017 roku mogliśmy pochwalić się, równie spektakularnym jak wcześniejsze wystawy, adresem - BOOKmacherzy pokazali się w Hali Stulecia we Wrocławiu podczas Wrocławskich Targów Dobrych Książek. Prezentacja została tym razem poszerzona o pokaz filmów. Publiczność Targów mogła na ekranie oglądać niepokazywane wcześniej, bo powstałe już w 2017 roku, studenckie książki. Co dla nas najważniejsze, współpraca z Wrocławskim Domem Literatury trwa nadal. Jan Choroszy zainicjował wydanie jednej z prac - autorskiej książki z elementami pop-up pt. Rekiny Alicji Grobelki przez wydawnictwo Warstwy ${ }^{8}$. Kolejne odsłony BOOKmacherów gościly także w Hali Stulecia podczas grudniowych Targów - w 2018 i 2019 roku?
W Pracowni Książki stale pojawiają się intrygujące pomysły i powstają ciekawe projekty książek. Staramy się prezentować je na bieżąco, zazwyczaj w ramach bardzo kameralnych odsłon BOOKmacherów, np. we wrocławskim Domku Miedziorytnika czy w uczelnianej Gablocie przy Rektoracie. Mamy już w planie następne wydarzenia. Przed nami pokaz BOOKmacherów w Galerii 36,6 Instytutu Sztuki Uniwersytetu Śląskiego w Cieszynie.

Oczywiście wszystkie wydarzenia, które udało nam się zorganizować, te, które dopiero planujemy, oraz kontakty, którymi zaowocowały, dają nam wiele satysfakcji. A szczególnie docenieni mogliśmy poczuć się wtedy, kiedy jako kuratorzy BOOKmacherów otrzymaliśmy nagrodę zespołową za osiągnięcia dydaktyczne przyznaną w 2018 roku przez Ministra Kultury i Dziedzictwa Narodowego ${ }^{10}$.

${ }^{1}$ Na Wydziale Grafiki i Sztuki Mediów Akademii Sztuk Pięknych im. Eugeniusza Gepperta we Wrocławiu.

${ }^{2}$ Nasza wystawa została wpisana w cykl prezentacji artystów związanych z Akademią Sztuk Pięknych im. Eugeniusza Gepperta we Wrocławiu, odbywających się w NFM pod hasłem „Rezonanse Sztuki”.

${ }^{3}$ Cytat z tekstu Tomasza Brody, jednego z kuratorów wystawy w NFM, umieszczony na stronie internetowej ASP i w mediach społecznościowych.

${ }^{4}$ Wybrany nailepszym dyplomem 2017 roku na ASP we Wrocławiu.

${ }^{5}$ Wydanie Skaczącego Myszki z ilustracjami Julity Nowosad było częścią nagrody

w konkursie zorganizowanym przez wydawnictwo Biuro Literackie we współpracy z Katedrą Projektowania Graficznego w 2011 roku. Po studiach autorka skoncentrowała się na grafice warsztatowej. Diana Karpowicz i Weronika Przybylska (obecnie Tarka) natomiast nadal są aktywnymi ilustratorkami.

${ }^{6}$ Wystawa była prezentowana w Narodowym Forum Muzyki od 16 listopada 2016 roku do 22 lutego 2017 roku.

${ }^{7}$ Art and Design University of Cluj-Napoca.

${ }^{8}$ Wydawnictwo jest częścią Wrocławskiego Domu Literatury.

${ }^{9}$ Kolejne odsłony BOOKmacherów: 1. „BOOKmacherzy. Wystawa książek i ilustracii studentów i pedagogów Katedry Projektowania Graficznego ASP we Wrocławiu”, Narodowe Forum Muzyki, listopad 2016-luty 2017 roku; 2. „BOOKmacherzy / THE ART OF THE BOOK. Wystawa książek i ilustracji studentów i pedagogów Katedry Projektowania Graficznego ASP we Wrocławiu", Galeria Casa Matei na Uniwersytecie Artystycznym w Cluj-Napoca, Rumunia, marzec 2017 roku; 3. „BOOKmacherzy. Odsłona II”, Hala Stulecia we Wrocławiu, 26. Wrocławskie Targi Dobrych Książek, 30 listopada-3 grudnia 2017 roku; 4. „BOOKmacherzy. Odsłona III”, Galeria Przy Rektoracie, Akademia Sztuk Pięknych im. Eugeniusza Gepperta we Wrocławiu, 5 marca-30 marca 2018 roku; 5. „BOOKmacherzy. Odsłona IV”, Domek Miedziorytnika we Wrocławiu 5 lipca-30 sierpnia 2018 roku; 6. „BOOKmacherzy. Odsłona V”, Hala Stulecia we Wrocławiu; 27. Wrocławskie Targi Dobrych Książek, 29 listopada-2 grudnia 2018 roku; 7. „BOOKmacherzy. Ilustracja z Pracowni Książki”, Gablota Przy Rektoracie, Akademia Sztuk Pięknych im. Eugeniusza Gepperta we Wrocławiu, styczeń-marzec 2019 roku; 8. „BOOKmacherzy. Przegląd Portfolio”, Prezentacja ekranowa i pokaz prototypów studenckich książek Klub Proza / Wrocławski Dom Literatury, 18 listopada 2019 roku; 9. „BOOKmacherzy. Pracownia Książki”, Hala Stulecia we Wrocławiu, 28. Wrocławskie Targi Dobrych Książek, 29 listopada-2 grudnia 2019 roku.

${ }^{10}$ Nagroda Ministra Kultury i Dziedzictwa Narodowego - nagroda zespołowa za osiągnięcia dydaktyczne. Fotorelacja z wernisażu BOOKmacherów, https://www.asp.wroc.pl/?module=News\&controller=Read\&action=news\&id=10616 (dostęp: 14.02.2020). Link do ilustracji: http://cojestgrane24.wyborcza.pl/cjg24/1,13,20991399,148971,BOOKmacherzy-wNarodowym-Forum-Muzyki--DUZO-OBRAZK.html (dostęp: 14.02.2020). 